\title{
Land use and land cover effect on groundwater storage
}

\author{
Ajay Prabhakar ${ }^{1} \cdot$ Harinarayan Tiwari ${ }^{2}$
}

Received: 24 September 2015/Accepted: 7 November 2015/Published online: 23 November 2015

(C) Springer International Publishing Switzerland 2015

\begin{abstract}
This study aims at assessing the effects of different strategies for groundwater recharge and storage in Indira Sagar Canal Command Area, Madhya Pradesh, India. Enlarged impervious area is the most important factor to decreased infiltration of ground water. The ground water storage is depleting due to above mentioned fact and extraction of more groundwater to fulfill the demand of rapidly growth urbanization with constant surface water available In this regard, estimating and managing groundwater resources require the integration of variety of discipline at a single platform. Therefore, several land-use changes, groundwater recharge, groundwater storage equation, preparation of digital elevation model and drainage density scenarios were setup and their effects on water balance and groundwater dynamics analyzed with the help of geographical information system. The groundwater storage of some village is found to be increasing after the canal construction (land-use change). This is due to fact that the demand of water is met by the canal supply and improved greenery results in higher the infiltration to the aquifer in many locations within the study area. This type of project is the need of the hour where there is water scarcity. The study witnessed increased socioeconomic condition of people due to the irrigation system which ensures round the year cultivation. Indira Sagar Canal Command has enhanced the food production in the district and state as a whole.
\end{abstract}

Harinarayan Tiwari

haribit31@outlook.com

1 National Institute of Technology, Kurukshetra, India

2 Indian Institute of Technology, Roorkee, India
Keywords Land-use change - Groundwater storage · Groundwater recharge $\cdot$ Rainfall infiltration factor - India

\section{Introduction}

Understanding the process of groundwater recharge is fundamental to the management of groundwater resources (Jyrkama and Sykes 2007; Tanner and Hughes 2015). Depending on the rainfall intensity, temperature, and ground surface cover, the precipitated water is subjected to various processes such as interception, evaporation, and surface runoff. A portion of the water may also infiltrate into the soil, where it may be taken up by the plant roots and subsequently transpired through the vegetation canopy. The remaining water will continue percolating deeper into the soil column, eventually becoming groundwater recharge when crossing the water table into the saturated groundwater zone (Deng et al. 2015). Groundwater is intimately connected with the landscape and land use that it underlies and most of the landscape and is vulnerable to the anthropogenic activities on the land surface above. Land use affects groundwater resources through changes in recharge and by changing demands for water (Fan 2015; Lerner and Harris 2009; Tetzlaff et al. 2007).

Providing assured water supply for irrigation is becoming the difficult task, with limited sources water and uneven distribution of water in space and time. The impact of urbanization on groundwater has a major concern to most urban area over past few decades, and in particular, to those involved in groundwater quantity and qualitative studies (Morris et al. 1994; Salvadore et al. 2015; Schirmer et al. 2013). Increased impervious area has been major factor in contributing to decreased infiltration, which results in decreasing groundwater storage. Large pressure 
of growing population, increased demands for food, fodder and fuel combined with industrial activities have essentially led to rapid change in land use purpose patterns in developing countries. Information on the rate and kind of change in the land resources is essential for proper planning, management and regularizing the use of such resources. Land use information is needed in the analysis of environmental processes and problem. It is necessary to understand the surrounding at present conditions and standards to be improved or remained at current level. Information on existing land use, its spatial distribution and its changes are essential prerequisite for planning and management Land-use planning and management strategies hold key for development of region. It has been reported that in many parts of the country the water table is declining at the rate of 1-2 m/year (Singh and Singh 2002). At the same time in some canal commands, the water table rise is as high as $1 \mathrm{~m} /$ year.

\section{Methods and materials}

\section{Study area}

The Indira Sagar Canal Command Area is located near Punasa village in Khandwa District of Madhya Pradesh
(Fig. 1). It is a multipurpose River Valley Project for development of water resources of Narmada which envisages an annual irrigation potential of 1.69 lakh hectare (ha) and generation of $1000 \mathrm{MW}$ of hydropower. Construction of the Indira Sagar Pariyojana began in 1984. A lined gravity canal takes off from the reservoir with FSL of $239.15 \mathrm{~m}$ through a $3.67 \mathrm{~km}$ long tunnel named Punasa tunnel. The study area extends between $74^{\circ} 46^{\prime}$ to $76^{\circ} 29^{\prime} \mathrm{E}$ longitude and $21^{\circ} 46^{\prime}$ to $22^{\circ} 19^{\prime}$ of north latitude and covers area is about $3550 \mathrm{~km}^{2}$. The elevation of study area varies from 84 to 320 Mean Sea Level (MSL).The command area receives annual rainfall of is $916.6 \mathrm{~mm}$ of which maximum rainfall during south-west monsoon period i.e. June to September. About $90.5 \%$ of the annual rainfall received during monsoon season. Only $9.5 \%$ of the annual rainfall takes place between Octobers and May period.

The mean daily maximum temperature in the basin varies from 27.7 to $40.4{ }^{\circ} \mathrm{C}$ and the mean daily minimum temperature varies from 20.6 to $27.2^{\circ} \mathrm{C}$. The land use map for the year 2000 is derived from topo maps using Arc/Info. Digital images for 2000 (Landsat TM), and 2010 (Landsat TM) are used to derive the land use maps by digital image process. Visual image interpretation of satellite data is carried out using an interpretation key generated through field survey and verifications. The ground checks are made for confirming the land use units. The different land-use for

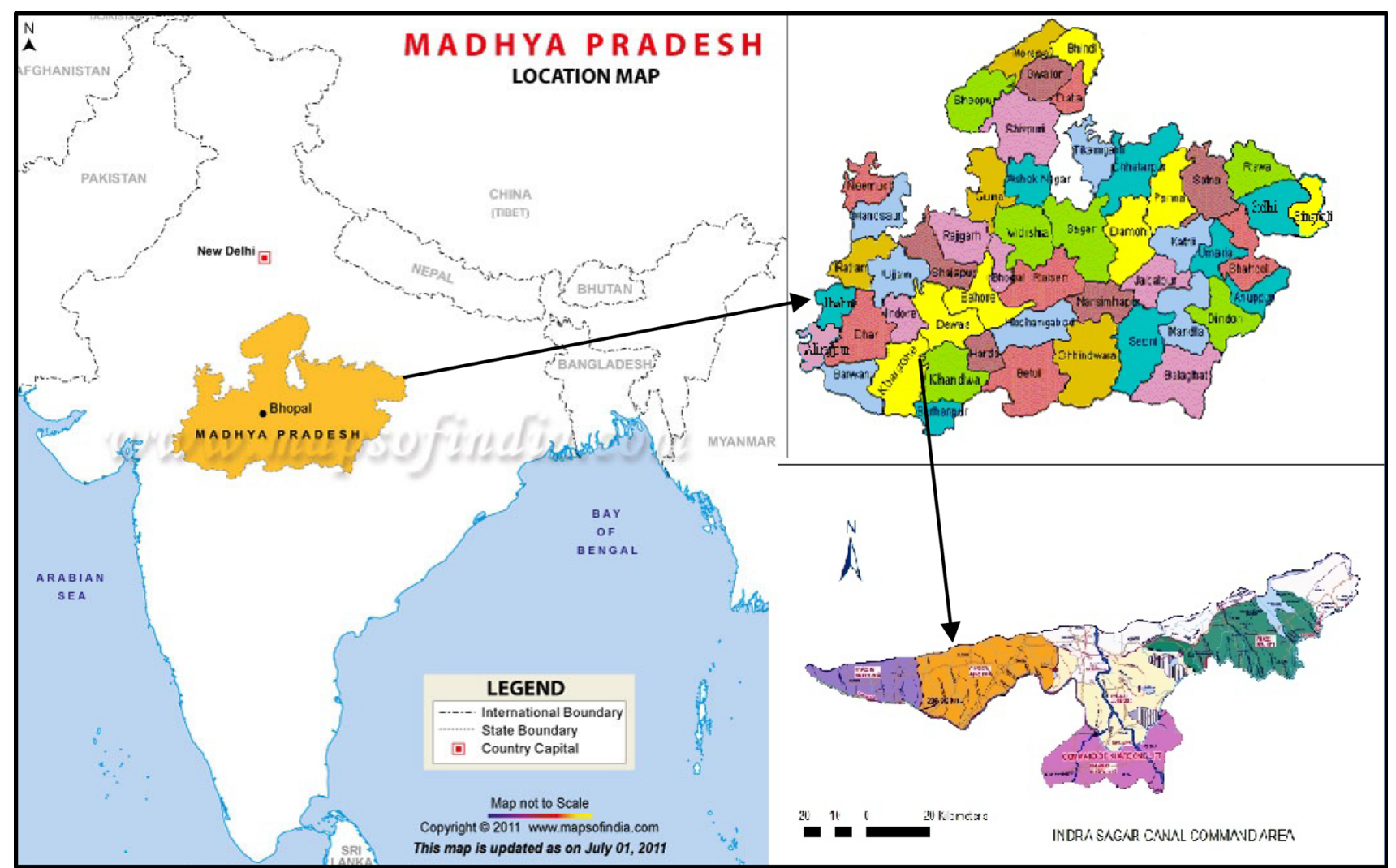

Fig. 1 Location of Indira Sagar Canal Command Area 
years 2000 and 2010 is shown in Table 3. Most of the recharge area of Narmada Valley is on the Madhya Pradesh state. The some part of the rechargeable areas is confined in high flat plains and alluvial low plains. Due to slope, the rainfall is converted quickly into runoff than infiltration through the ground and joining the nearest tributaries.

\section{Topography}

The Narmada River is the fifth largest river in India and the largest west flowing river of Indian peninsula. It is known as the life line of Madhya Pradesh and Gujarat, originating from Amarkantak in the district of Shahdol (Madhya Pradesh). It travels a distance of $1312 \mathrm{~km}$, before meeting the Arabian sea in Gulf of Cambay in Gujarat, out of which $1077 \mathrm{~km}$ is in the state of Madhya Pradesh covering the districts of Shahdol, Dhindori, Mandla, Jabalpur, Hoshangabad, Harda, Khandwa, Khargone, Barwani, Dhar and Jhabua. Narmada River is an inter-state river.

The whole catchment area is about $61,000 \mathrm{~km}^{2}$ and Indira Sagar Canal Command Area is of about $3550 \mathrm{~km}^{2}$. The main canal of Indira Sagar Project is $248.65 \mathrm{~km}$ long. The project envisages annual irrigation of 1.69 lakh ha in a Culturable Command Area (CCA) of 1.23 lakh ha in 571 villages of Khandwa, Khargone and Barwani districts as per the details given below (Tables 1, 2).

\section{Digital elevation model}

There are various ways of representing continuous surfaces in digital form using a finite amount of computer memory capacity. For the purposes of GIS models, DEM is the most

Table 1 Irrigation supply plan by Indira Sagar Project canal command area

\begin{tabular}{llll}
\hline S. no. & District & Irrigation (in lakh ha) & No. of villages \\
\hline 1. & Khandwa & 0.31 & 76 \\
2. & Khargone & 0.91 & 345 \\
3. & Barwani & 0.48 & 150 \\
Total & & 1.69 & 571 \\
\hline
\end{tabular}

convenient means for representing the earth's surface (Gumbo 2011; Gumbo et al. 2002; Gumbo and Van der Zaag 2002). Precision of the hydrological study depends up to a great extent on the interval of elevation information, which is used for preparation of DEM. Small is the interval precision will be high. In the first step, all the data have been converted to digital format, by digitization of existing maps and well locations. Remote sensing data are already in digital format. The second step involves generation of thematic layers of information from different sources. It involves digital image processing of remote sensing data and further processing of existing maps and old data for extraction of pertinent information (Chowdhury et al. 2010; Jha et al. 2010).

\section{Image classification}

The purpose of digital land cover classification is to link the spectral characteristics of the image to a meaningful information class value, which can be displayed as a map so that resources managers or scientist can evaluate the landscape in accurate and cost-effective manner (Weber and Dunno 2001). The overall objective of image classification procedures is automatically categorize all pixels in an image into land cover classes. This may be achieved by either visual or computer aided analysis.

A large number of classification exist methods which are generally known as unsupervised and supervised classification. The classification may be either by an unsupervised method that groups cases by their relative spectral similarity or by a supervised method based on similarity of cases to asset of predefined classes that have been characterized spectrally. Areas occupied by each land use for each Command area were determined using the supervised classification in ERDAS IMAGINE (9.2) AOI and Signature Editor Tool.

\section{Recharge assessment based on rainfall infiltration factor}

Recharge can be estimated based on the rainfall infiltration factor method. Recharge from rainfall in monsoon season is given by Eq. (1)

Table 2 Salient features

\begin{tabular}{ll}
\hline Canal alignment & Command area (lakh ha) \\
\hline (i) Length of main canal (M) 248.65 & (i) Gross Command Area 2.10 \\
(ii) Head discharge (Cumec) 160 & (ii) Culturable Command Area 1.7 \\
(iii) Full supply level (M) 239.15 & (iii) Irrigated Area 1.23 \\
(iv) Bed width (M) 16.4 & (iv) Annual Irrigation 1.69 \\
(v) Full supply depth (M) 9.0 & \\
\hline
\end{tabular}




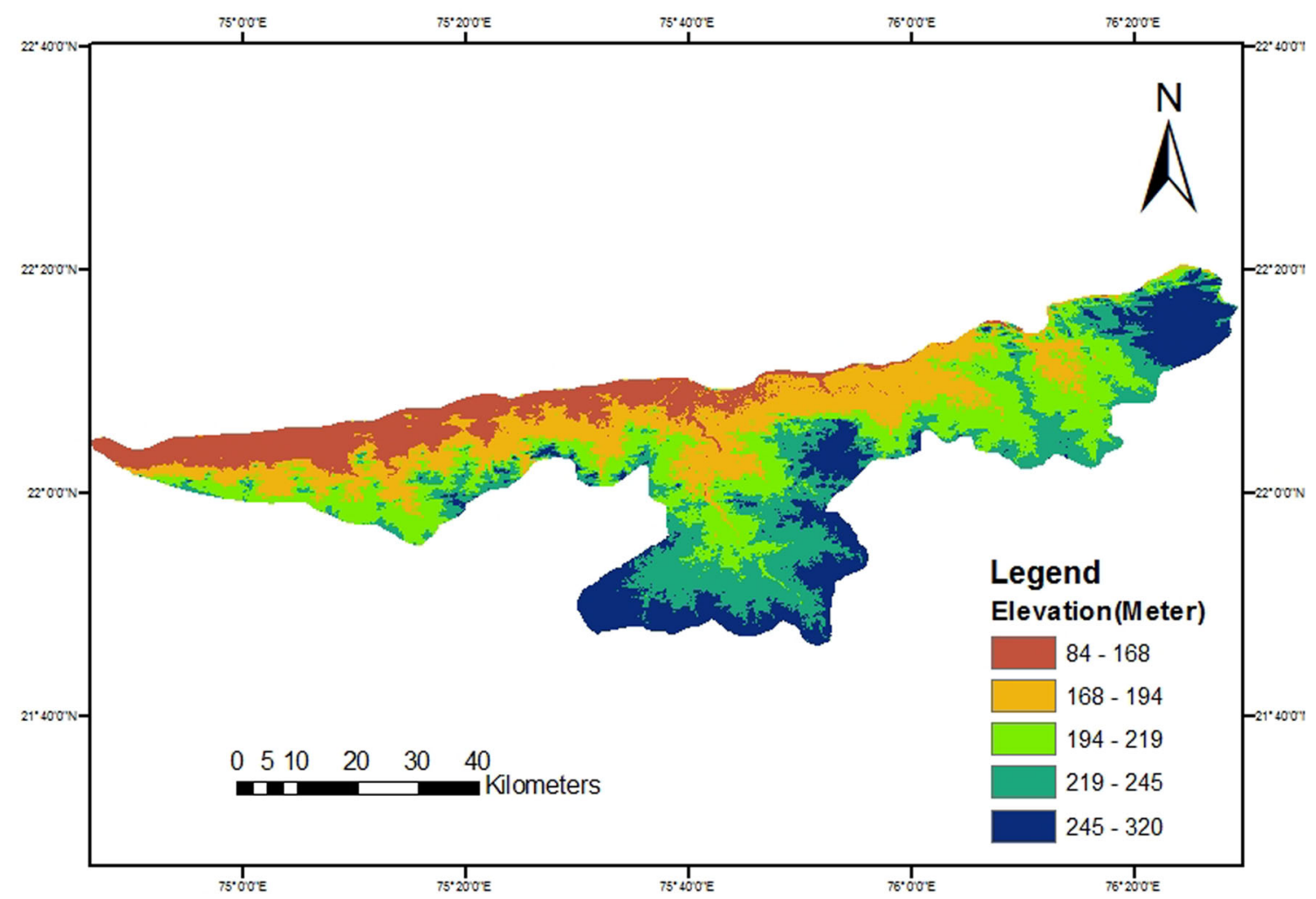

Fig. 2 Digital elevation model (DEM) of the study area

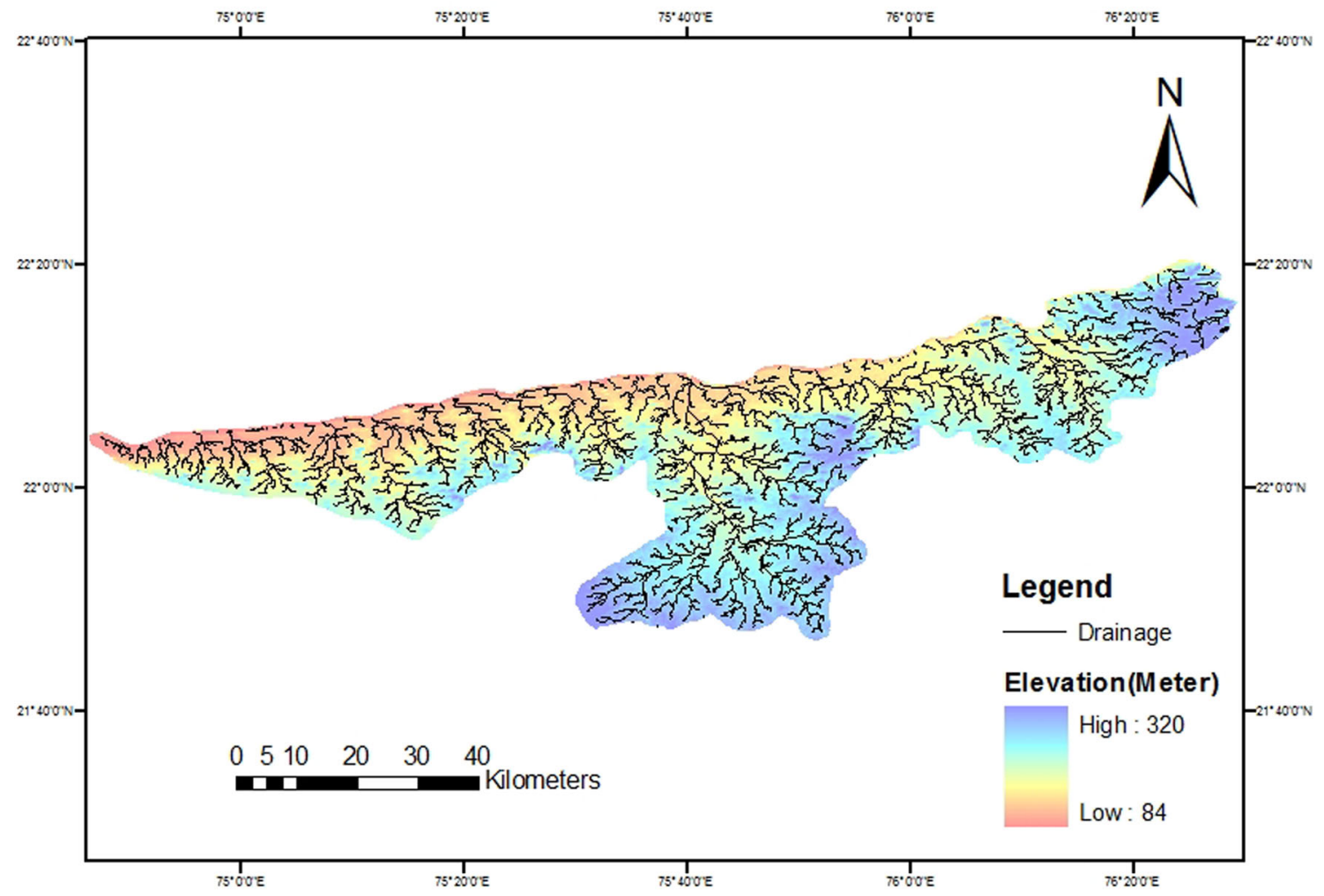

Fig. 3 Drainage density map of the study area 
$\mathrm{Re}_{r f}=f A N_{r}$

where $\mathrm{Re}_{\mathrm{rf}}$, Recharge due to Rainfall; A, Area of computation for recharge; $\mathrm{N}_{\mathrm{r}}$, Normal rainfall in monsoon; $f$, Rainfall Infiltration factor.

The same recharge factor may be used for both monsoon and non-monsoon rainfall, with the condition that the recharge due to non-monsoon rainfall may be taken as zero, if the normal rainfall during the non-monsoon season is less than $10 \%$ of normal (GEC-2009) annual rainfall (Chatterjee et al. 2009; Chatterjee and Purohit 2009). The most part of study area considered under alluvial soil

Table 3 Land-use and land-cover for Indira Sagar Command Area (in sq. km) (Zinck et al. 2001)

\begin{tabular}{lcccc}
\hline Land-use types & $2000(\%)$ & $2000\left(\mathrm{~km}^{2}\right)$ & $2010(\%)$ & $2010\left(\mathrm{~km}^{2}\right)$ \\
\hline Water bodies & 0.43 & 15.28 & 1.33 & 47.12 \\
Mixed plant & 7.61 & 270.16 & 11.96 & 424.50 \\
Grass and shrubs & 18.50 & 656.65 & 29.97 & 1063.95 \\
Fallow land & 52.02 & 1846.64 & 29.06 & 1031.48 \\
Agricultural land & 15.09 & 535.57 & 18.19 & 645.75 \\
Urbanization & 6.36 & 225.70 & 9.50 & 337.19 \\
Total area & 100.00 & 3550.00 & 100.00 & 3550.00 \\
\hline
\end{tabular}

series. The Recommended Value for rainfall infiltration factor is $10 \%$ by GEC1997 (Chatterjee et al. 2009; Chatterjee and Purohit 2009). The soil property is assumed same for whole command area for this study. Recharge due to rainfall infiltration factor for study area has been preferred by calculating the average of normal monsoon rainfall data for whole year in two locations of study area. The calculated values from above assumptions have been used in above formula Eq. (1) and the results are shown below (Table 4; Fig. 6).

\section{Identification of groundwater storage}

For this study, 21 wells have been considered in the study area. The data were collected from Water Resources Department, District Khandwa, Madhya Pradesh. Groundwater storage per year calculated using well data. The data of pre monsoon season and post monsoon seasons were used to plot the water level contour of study area. Both techniques recharge due to rainfall using rainfall infiltration factor and ground water storage equation are utilized in this study to find out storage and recharge of Indira Sagar Canal Command Area.

The Recommended Value for specific yield is $6 \%$ by GEC 1997. The soil property is assumed same for whole

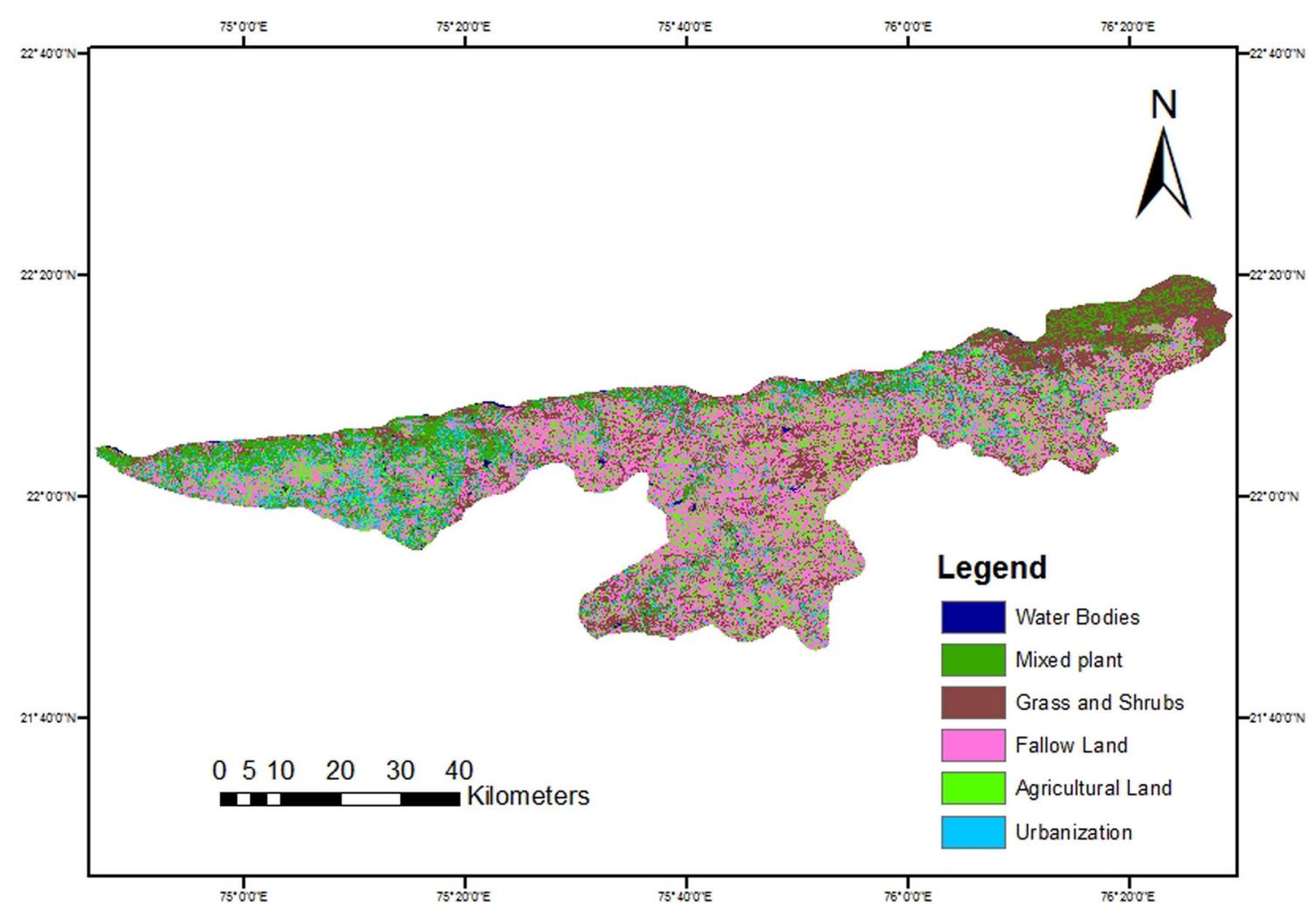

Fig. 4 Land use and land cover map (year 2000) 
command area for this study and in the absence of any pumping test.

Information for the study area of $3550 \mathrm{~km}^{2}$, a specific yield value of 0.06 has been taken as recommended by Geological Estimation Committee (GEC 1997) considering the clayey soil Alluvium.

\section{Ground water balance equation}

The water level fluctuation method is based on the application of ground water balance equation, which is stated in general terms as follows for any specified period,

Storage Increase $=$ Input - Outflow

$S=(R r+R c+R i+R t+S i)-(E t+T p+S e+O g)$

where $R r$, Recharge from rainfall; $E t$, Evapotranspiration from groundwater; $R c$, Recharge from canal seepage; $T p$, Draft from groundwater; $R i$, Recharge from field irrigation; $S e$, Effluent seepage to rivers; $R t$, Recharge from tanks; $O g$, Outflow to other basins; and $S i$, Influent seepage from rivers; $S$, Change in groundwater storage.

In the above Eqs. (2) and (3), the terms input and output are used in the general sense, referring to all components of ground water balance, which are either input to the unit, or output from the unit of ground water system taken up for resource assessment (ex: watershed, block etc.). Hence input refers to recharge from rainfall and other sources and subsurface inflow into the unit. Output refers to ground water draft, ground water evapotranspiration, and base flow to streams and subsurface outflow from the unit.

Storage can be given as a function of the ground water level change and specific yield. Hence ground water level measurements at the beginning and end of the season form necessary input for the estimation of storage change (GEC1997) (Chatterjee and Purohit 2009).

\section{Storage equation}

The storage equation used to find out groundwater storage is as follow:

$S=\Delta h S_{\gamma} A$

where $S$, Storage; $\Delta h$, Change in well depth; $S_{\gamma}$, Specific yield.

The estimation of groundwater storage of some village has been done by using the storage equation. The specific yield values considered in the computations are to be taken preferably from field tests, in the absence of which, the

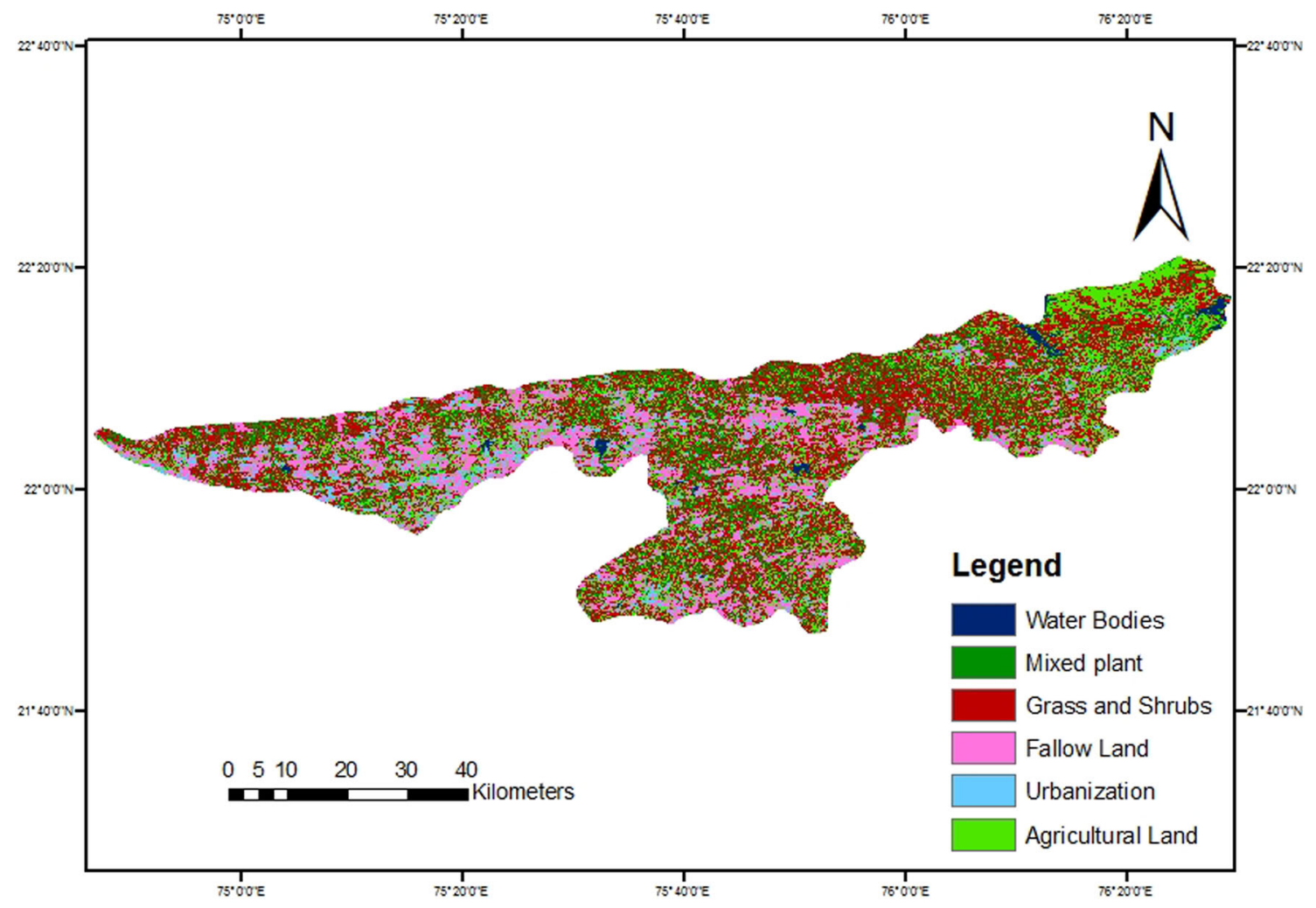

Fig. 5 Land use and land cover map (year 2010) 
Table 4 Year-wise recharge due to rainfall

\begin{tabular}{|c|c|c|c|c|c|c|c|c|c|c|c|}
\hline Years & 2000 & 2001 & 2002 & 2003 & 2004 & 2005 & 2006 & 2007 & 2008 & 2009 & 2010 \\
\hline Recharge due to rainfall $\left(\mathrm{km}^{3}\right)$ & 0.17 & 0.18 & 0.25 & 0.37 & 0.28 & 0.22 & 0.45 & 0.38 & 0.20 & 0.30 & 0.30 \\
\hline
\end{tabular}

Table 5 Groundwater storage of six has been selected wells in study area

\begin{tabular}{|c|c|c|c|c|c|c|}
\hline \multirow[t]{2}{*}{ Village } & \multicolumn{6}{|l|}{ Storage $\left(\mathrm{km}^{3}\right)$} \\
\hline & Badwani (W1) & Borlai (W2) & Chhegaon (W3) & Punasa (W4) & Punasa (W5) & Punasa (W6) \\
\hline \multicolumn{7}{|l|}{ Years } \\
\hline 2000 & 0.703 & 0.662 & 0.298 & 0.486 & 0.937 & 0.554 \\
\hline 2001 & 0.351 & 0.511 & 0.258 & 0.856 & 0.170 & 0.256 \\
\hline 2002 & 0.650 & 1.097 & 0.288 & 0.609 & 0.852 & 0.405 \\
\hline 2003 & 1.118 & 0.899 & 0.373 & 0.586 & 0.809 & 1.257 \\
\hline 2004 & 0.948 & 1.289 & 0.469 & 1.112 & 0.831 & 1.214 \\
\hline 2005 & 0.486 & 0.703 & 0.639 & 1.864 & 1.108 & 1.108 \\
\hline 2006 & 0.767 & 0.916 & 0.501 & 0.564 & 0.767 & 1.140 \\
\hline 2007 & 1.150 & 1.097 & 0.320 & 0.477 & 1.065 & 0.767 \\
\hline 2008 & 1.299 & 1.480 & 0.599 & 1.304 & 0.831 & 0.692 \\
\hline 2009 & 1.267 & 1.282 & 0.841 & 0.528 & 0.937 & 0.820 \\
\hline 2010 & 1.355 & 1.389 & 0.675 & 0.886 & 0.797 & 0.788 \\
\hline
\end{tabular}

Fig. 6 Groundwater recharges variation v/s year from 2000 to 2010

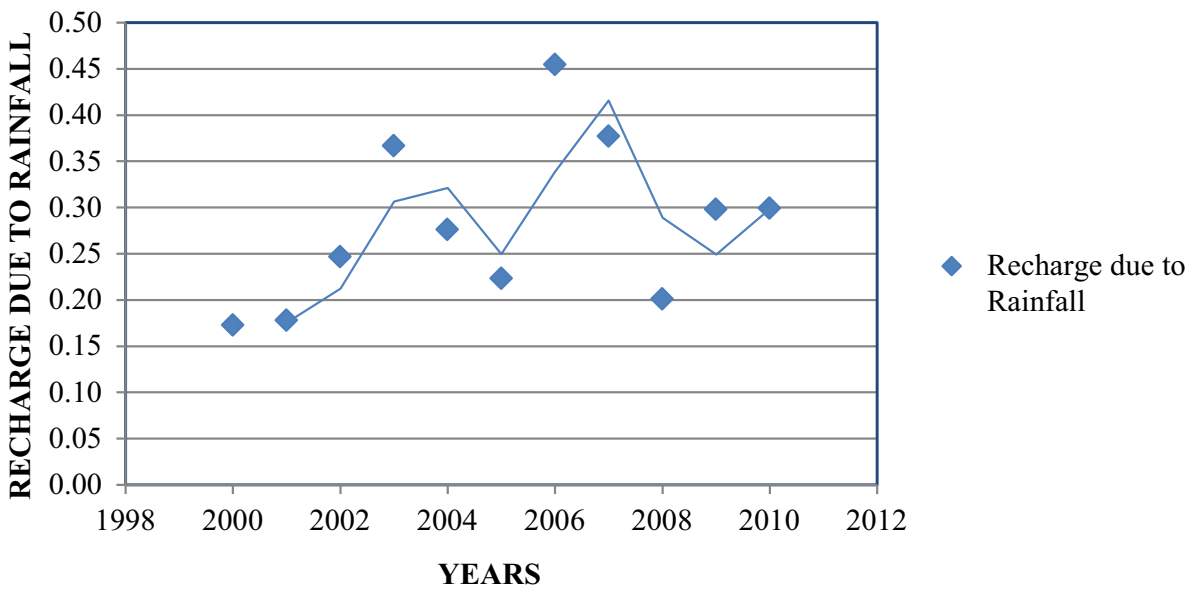

recommended values of specific yield are $6 \%$ to be considered (Chatterjee et al. 2009) and study area $\left(A=3550 \mathrm{~km}^{2}\right)$. Pre and post monsoon data were collected from Water Resources Department, District Khandwa from year 2000 to 2010. Selected six well locations for ground water storage (Table 4) show the condition of Ground water Storage of some wells in Indira Sagar Canal Command Area. The Dam was constructed in Punasa Village in Khandwa district in Madhya Pradesh. The dam was completed in year 2004. The Three District Barwani, Khargone and Khandwa lies in command Area.
Some village Ground water storage is found out by using the storage Eq. (4). Ground Water level remained stabilizes in many places due to the Canal. Due to supply of water from Lined canal to the irrigation field.

The pre monsoon well data and post monsoon well data have been used to show the Pre Monsoon and Post Monsoon well levels and change in depth for the year 2000, 2005 and 2010 of some villages which come inside the boundary of Indira Sagar Canal Command Area. The change in depth of well level is equal to the difference of Pre and Post Monsoon well level. 


\section{Results and discussions}

A DEM is a numerical representation of landscape topography. DEM can be used to derive a wealth of information about the morphology of land surface by means of algorithms in raster processing systems, which use neighbourhood operations. These algorithms provide information such as flow direction, flow accumulation, drainage network, slope aspect and overland flow path. The elevation of study area varies from 84 to 320 Mean Sea Level (Fig. 2) and Drainage density (Fig. 3).

The purpose of digital land cover classification is to link the spectral characteristics of the image to a meaningful information class value, which can be displayed as a map so that resources managers or scientist can evaluate the landscape in accurate and cost-effective manner (Dunno February 2001). Table 3 shows the change in land-use types which shows due to construction of Indira Sagar Canal Command Project, many changes found in command area as the fallow land converted into cultivative land and greenery of command area is also increasing. The stress on ground water is deceases due to surface water availability. Classified image shown below (Figs. 4, 5).

The recharge due to rainfall has been calculated in Table 3. It is found out that the recharge due to rainfall not varies much in every year. Before year 2004 the ground water trend was going down due to more stress on ground water because it was used for both drinking and irrigation purpose. Since the construction of Indira Sagar Canal Project has been started water is being supplied by canal for irrigation purpose.

The difference of recharge of water (Inflow) and Extraction of water (outflow) is equal to storage of ground water storage. The Table 4 shows that changes in storage in selected village and it can be inferred that after the canal construction the ground water storage trend is sustained and many places the ground water storage trend is increasing. The surface water availability, the stress on ground water is decreasing and irrigation is possible throughout the year. The ground water storage trend of some village is considered to shows groundwater changes in Indira Sagar Command Area are shown in Table 4; Figs. 2, 3, 4 (Table 5; Figs. 6, 7, 8, 9).

The change in depth is equal to the difference of Pre and Post Monsoon. The Data of all Villages wells which comes inside the Indira Sagar Canal Command Area are consider to show the Pre Monsoon level and Post Monsoon level and Fluctuation in depth of the Villages for year 2000, 2005 and 2010. Changes in groundwater level of wells in some villages of study area are shown in Figs. 10, 11, and 12.

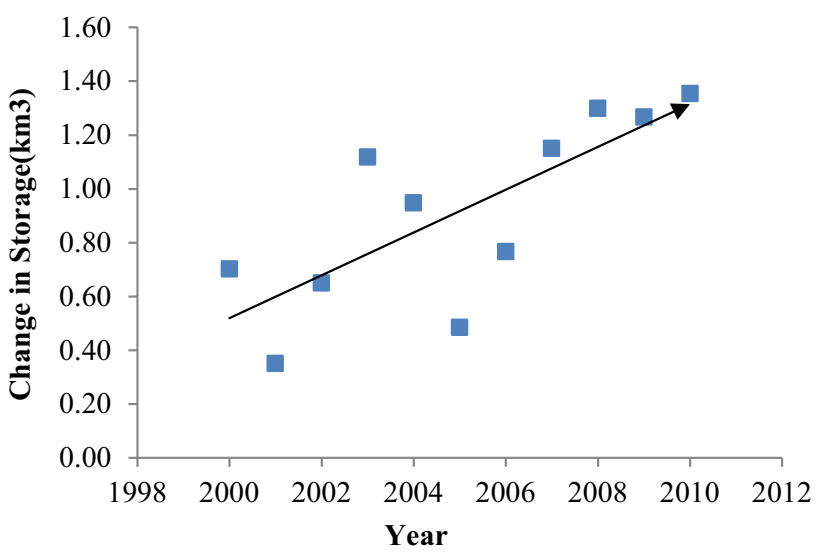

Fig. 7 The groundwater storage v/s year, Badwani village in District Barwani

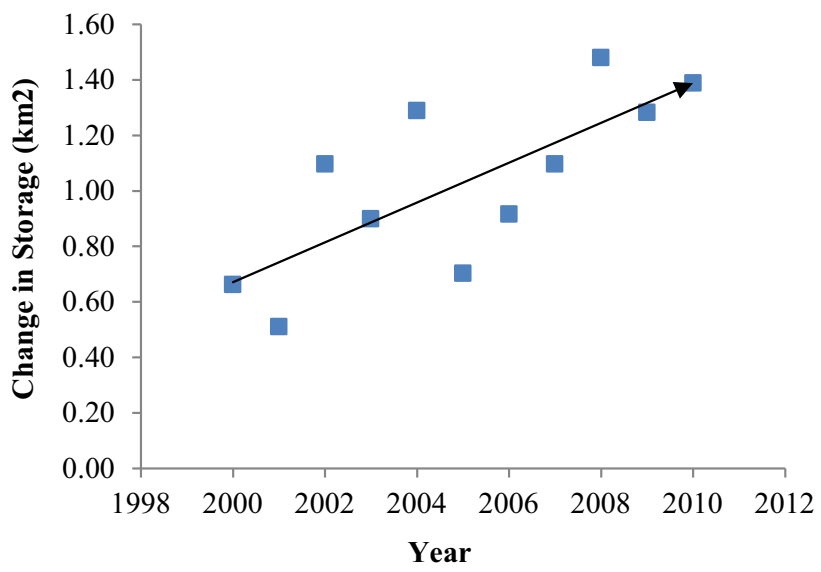

Fig. 8 The groundwater storage v/s year, Borlai village in District Barwani

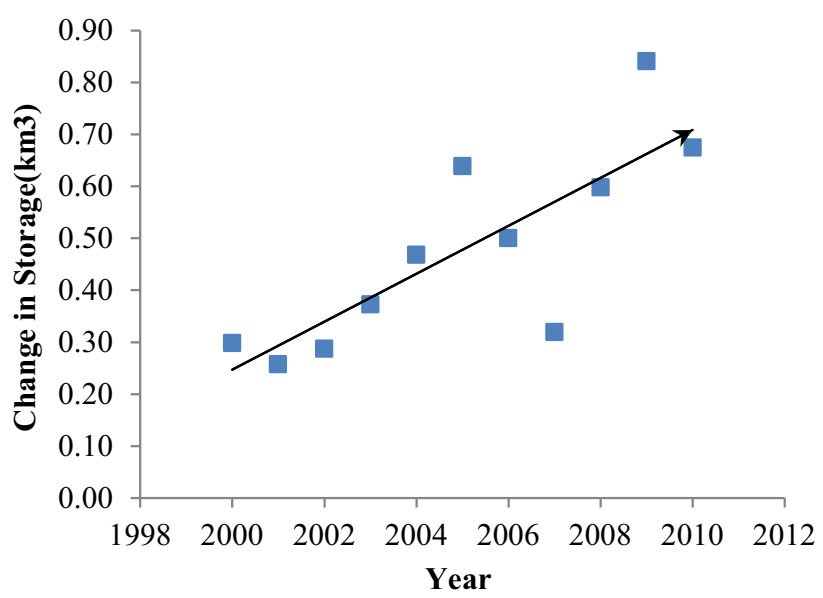

Fig. 9 The groundwater storage v/s year, Chhegaon makhan village (Punasa) in District Khandwa 
Fig. 10 Pre and Post Monsoon well level and fluctuation in depth of well (year 2000)
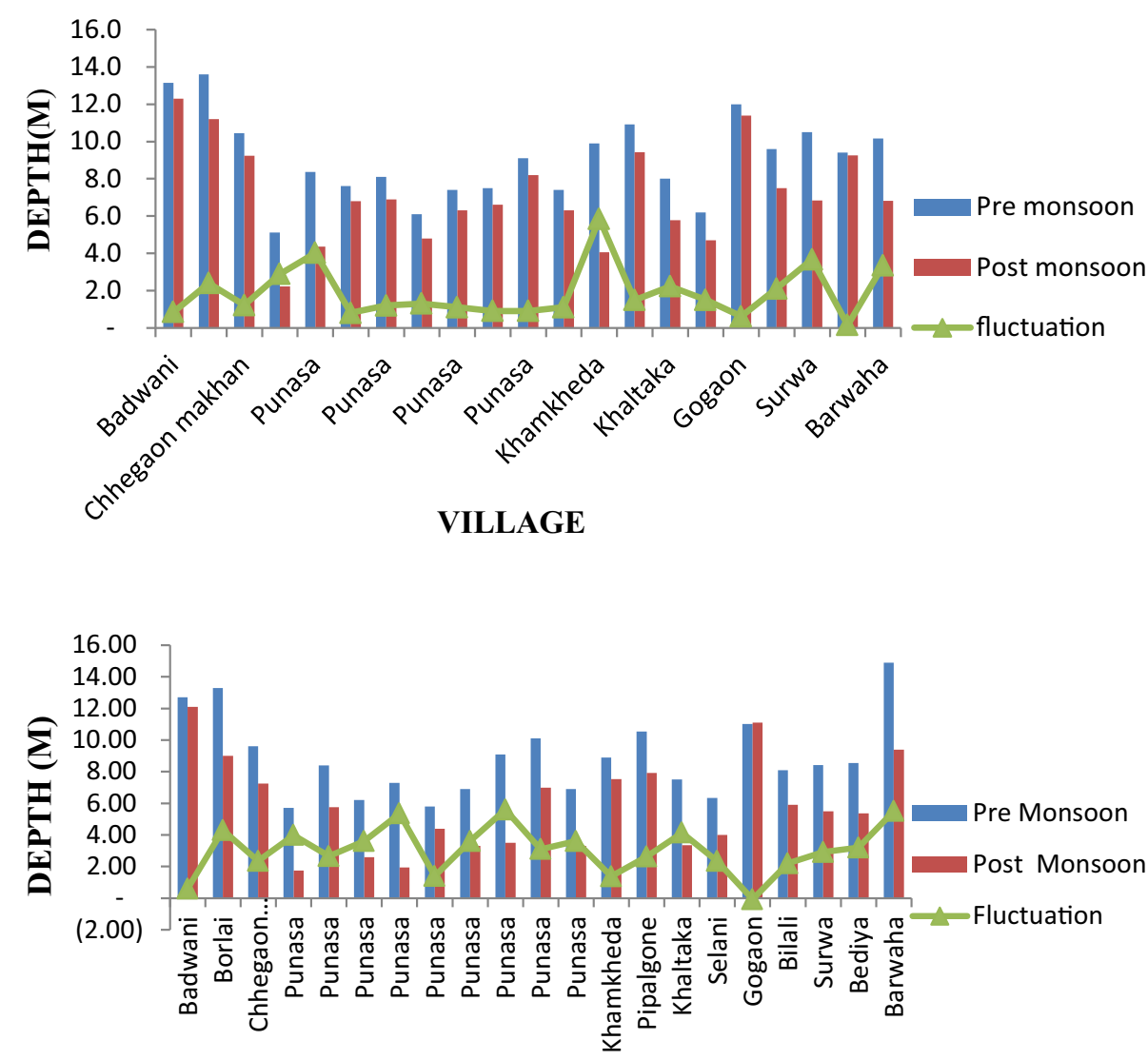

VILLAGE

Fig. 12 Pre and Post Monsoon well level and fluctuation in depth of well (year 2010)

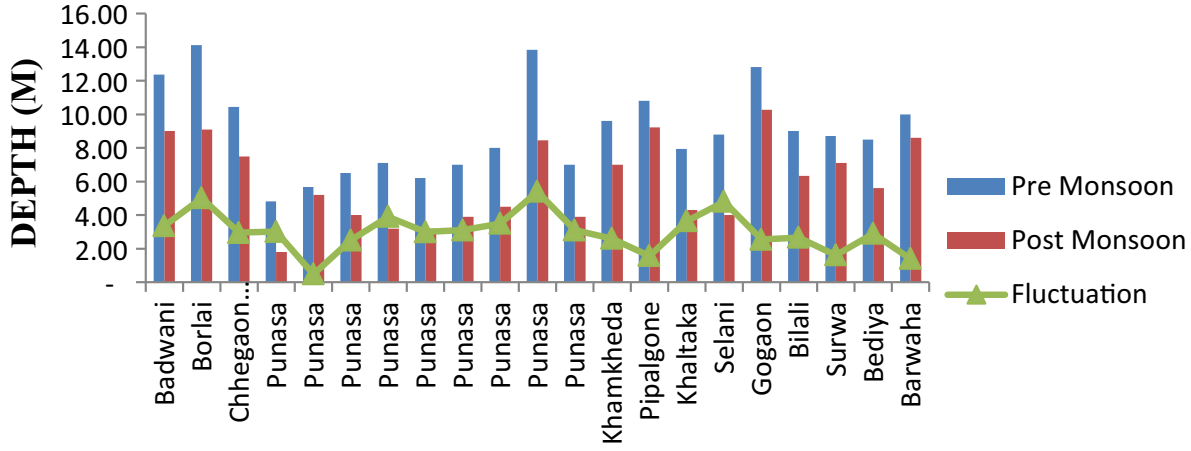

VILLAGE

\section{Conclusion}

The irrigation water, both surface and groundwater, plays a vital role in the sustainable command area development. Its timely availability and optimal management is necessary for improving the irrigation efficiency. Beside this, the land use change in an area affects the infiltration potential and groundwater storage thereby. The present study is an attempt to assess the land use change in groundwater storage in Indira Sagar Canal Command with an area of
$3500 \mathrm{~km}^{2}$ in Madhya Pradesh. It has been found from the study that the land use profoundly affects the groundwater storage in the region. Further, in the command fallow land is converted into cultivable land resulting in improved greenery. The cultivated land is supported by lined canal constructed after undertaking micro-level planning. If surface water is sufficiently available, the stress on groundwater utilization decreases resulting in increased groundwater storage in the command. The groundwater storage of some village is found to be increasing after the 
canal construction (land-use change). This is due to fact that the demand of water is met by the canal supply and improved greenery results in higher the infiltration to the aquifer in many locations within the study area. This type of project is the need of the hour where there is water scarcity. The study witnessed increased socio-economic condition of people due to the irrigation system which ensures round the year cultivation. ISP has enhanced the food production in the district and state as a whole.

\section{References}

Chatterjee R, Purohit RR (2009) Estimation of replenishable groundwater resources of India and their status of utilization. Curr Sci 96(12):1581-1591

Chatterjee R, Gupta B, Mohiddin S, Singh P, Shekhar S, Purohit R (2009) Dynamic groundwater resources of National Capital Territory, Delhi: assessment, development and management options. Environ Earth Sci 59(3):669-686

Chowdhury A, Jha MK, Chowdary V (2010) Delineation of groundwater recharge zones and identification of artificial recharge sites in West Medinipur district, West Bengal, using RS, GIS and MCDM techniques. Environ Earth Sci 59(6): $1209-1222$

Deng L, Wang W, Cai Y, Hu A, Tan L (2015) Groundwater diffuse recharge and its response to climate changes in semi-arid northwestern China. Terr Atmos Ocean Sci 26(4):451-461

Fan Y (2015) Groundwater in the Earth's critical zone-relevance to large-scale patterns and processes. Water Resour Res 51(5):3052-3069

Gumbo B (2011) Integrated urban flood management. UNDP, Pretoria

Gumbo B, Van der Zaag P (2002) Water losses and the political constraints to demand management: the case of the City of Mutare, Zimbabwe. Phys Chem Earth Parts A/B/C 27(11):805-813
Gumbo B, Munyamba N, Sithole G, Savenije HH (2002) Coupling of digital elevation model and rainfall-runoff model in storm drainage network design. Phys Chem Earth Parts A/B/C 27(11):755-764

Jha MK, Chowdary V, Chowdhury A (2010) Groundwater assessment in Salboni Block, West Bengal (India) using remote sensing, geographical information system and multi-criteria decision analysis techniques. Hydrogeol J 18(7):1713-1728

Jyrkama MI, Sykes JF (2007) The impact of climate change on spatially varying groundwater recharge in the grand river watershed (Ontario). J Hydrol 338(3):237-250

Lerner DN, Harris B (2009) The relationship between land use and groundwater resources and quality. Land Use Policy 26:S265S273

Morris BL, Lawrence AR, Stuart ME (1994) The impact of urbanisation on groundwater quality (project summary report). British Geological Survery, Nottingham, UK, WC/94/056 (Unpublished)

Salvadore E, Bronders J, Batelaan O (2015) Hydrological modelling of urbanized catchments: a review and future directions. J Hydrol 529:62-81

Schirmer M, Leschik S, Musolff A (2013) Current research in urban hydrogeology - a review. Adv Water Resour 51:280-291

Singh DK, Singh AK (2002) Groundwater situation in India: problems and perspective. Int J Water Resour Dev 18(4):563-580

Tanner J, Hughes D (2015) Surface water-groundwater interactions in catchment scale water resources assessments-understanding and hypothesis testing with a hydrological model. Hydrol Sci J (just-accepted)

Tetzlaff D, Soulsby C, Bacon P, Youngson A, Gibbins C, Malcolm I (2007) Connectivity between landscapes and riverscapes-a unifying theme in integrating hydrology and ecology in catchment science? Hydrol Process 21(10):1385-1389

Weber RM, Dunno GA (2001) Riparian vegetation mapping and image processing techniques, Hopi Indian Reservation, Arizona. Photogramm Eng Remote Sens 67(2):179-186

Zinck JA, López J, Metternicht GI, Shrestha DP, Vázquez-Selem L (2001) Mapping and modelling mass movements and gullies in mountainous areas using remote sensing and GIS techniques. Int J Appl Earth Obs Geoinform 3(1):43-53 